Emir. J. Agric. Sci. 2005. 17 (2): 30-40

http://www.cfa.uaeu.ac.ae/Research/EJAS.htm

\title{
Development of a tractor-mounted date palm tree service machine
}

\author{
Moustafa A. Fadel \\ Department of Arid Land Agriculture, College of Food and Agriculture, \\ U.A.E. University, Al-Ain, P.O. Box 17555
}

\begin{abstract}
A tractor-mounted date palm tree service machine was developed and tested. The developed system is attached to the rear of an 80- HP agricultural tractor. System's power source is the tractor hydraulic system, electrically controlled using the tractor's electric DC circuit. Using the traditional tractor increases its annual working hours and reduce capital cost. The machine has the capability to lift a service worker and the required tools to the crown zone as high as 4.5 meters. A hydraulically driven winch is available to lower the harvested dates in a clean basket to the ground. To protect the worker from any system failures, and the tree from operator mistakes, both human and tree safety features are considered in the design. Compared to the traditional way of serving palm trees, where a worker climbs the tree using a piece of rope, the system provides a safer and more comfortable working environment. The developed system was tested in the field and compared with manual traditional practices. It was found out that using the developed device increases worker's productivity.
\end{abstract}

Key words: Date palm mechanization, date palm, palm servicing, machine test.

\section{ظلوبر آلة الخمة أنجار النخلمعلفة خلفيا عل الجرار}



قسم زراعة الأرالي الفالة -كلية الأغنية والزراعة -جامعة الإمارل المربية المتحة

ملغص: مق طوير و تصنيع و لختبار آلة لخمة لمُشجار النخل معلقة على خلفية جرار زراعي ققلي دي ذوق درة 80

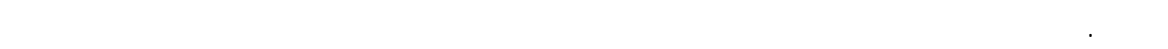

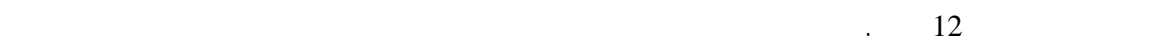

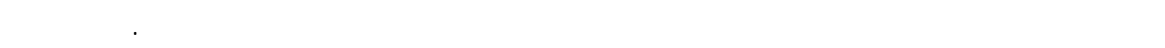

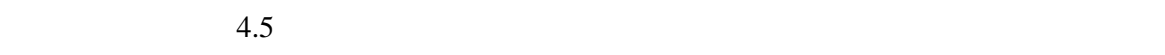

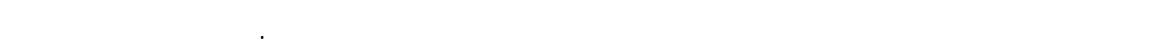

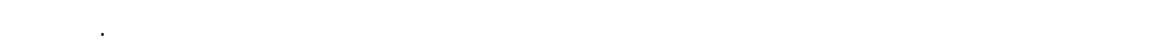


يوفر للعلل بيئة مريحة و آمنة للعطل. وقد مت لختبار الآلة حقليا و تمقم مقارنة النتائج بمعدلات الأداء القليية. كاملتففتاحية: ميكنة إنتاج التمور، آلة خدة لُشجار، رافعة على الجرار، إختبار آلات الخمة.

\section{Introduction}

Number of palm trees in the UAE exceeds 40 millions. Each tree should be serviced at least eight times a year. Servicing includes pollinating, pruning, cleaning and harvesting. A large number of workers is needed from the nearby countries such as India and Pakistan to serve such huge number of trees. Traditionally, when servicing a palm tree, the worker should climb it using a 


\section{Moustafa A. Fadel}

piece of rope and step on the old cut leaves and use them as a ladder. Little literature has been published regarding mechanization of date palm trees servicing.

As UAE agricultural sector dependence on date palm trees grows, and number of palm trees is suggested to increase rapidly in the next few years. Since there are no enough laborers to service the grown 40 million trees, suitable machinery is urgently needed to increase worker's productivity as well as improve date production quality.

The aim of this research work was to develop a tractor-mounted palm tree service machine which should provide a safe working environment, in addition to presenting some important tools to help the worker performing the needed practice in a more efficient fashion. The ability of this system to adopt different modules in the future was a design concern to guarantee a profitable multi purpose agricultural machine on the farm.

A single attempt was made by $\mathrm{Al}$ Suhaibani et al. (1990) in which they designed and built a prototype of a palm tree service machine with the cooperation of Cranfield Institute of Technology in U.K. Al-Janobi (2001) mentions that a prototype machine has been developed by the Department of Agricultural Engineering of King Saud University. He added that the design and development of this machine and others developed by researchers were mainly focused on taking the workers to the top of the tree for performing the required operations. The problems associated with those machines were safety, stability, speed, cost, and efficiency. He recommended considering a fully automated service machine. On the other hand, Al-Janobi (2001) and Brown
(1982) state that for many years, workers used extension ladders to climb into the producing palms as many as 10 times a year. Operations performed on the palms throughout the year following harvest include: clean up and dethorning; thinning; pollinating; tying down and bunch thinning; pruning and bagging, and finally harvesting of the next crop. He added that, a few growers built large tractor-pulled harvesting towers which eliminated the need for ladder and supported the workers for picking. He concluded that the towers were expensive, worker productivity was not increased significantly, and that the interest in towers eventually dropped.

Abdullah et al. (1986) developed a single walk-up elevator to suit date farming operations to elevate workers manually to the tree crown using two walking up foot pedals and a seat, and Hassan et al. (1986) modified an industrial lift to be used for date -crown related operations. They concluded that major modifications were needed in order to use the industrial elevator for date farming systems.

Al-Suhaibani et al. (1988) and AlSuhaibani et al. (1992) tested the prototype of a date palm service machine designed and built by Al-Suahibani et al. (1990) with the cooperation with Cranfield Institute of Technology in U.K. They reported that many agricultural operations, particularly harvesting, require the man to climb the tree and work at a considerable height above the ground. This is a dangerous operation compounded by a severe labor shortage in Saudi Arabia. The overall size, reach, ground clearance and power required by a machine was decided after a survey of date farms carried out in the country in 1985. The machine consists of an electro-hydraulic controlled basket 
mounted on a four-wheel-drive chassis. This is driven by a diesel engine used to enable the worker to be elevated into the tree or to power the wheels. The output of harvested dates in $\mathrm{kg} / \mathrm{man}$ hour is greater with the machine than with traditional hand harvesting. However, the machine is much slower to reach a given position in the trees than is the case with traditional harvesting.

The latest published research paper in this field was presented in 2004 in which Abonajimi (2004) focused on the development of date fruit harvesting machinery.

\section{Prototype design and development}

Phase one of this project focused on studying physical properties of local palm tree cultivars; the collected data was used to design the system. The other two phases included the design and testing of the elevator and safety issues. The main goals of the system were to raise the worker and locate him safely where he can perform the seasonal practice in the palm tree crown zone, and in addition to provide some tools to improve the quality of harvested date fruits and worker productivity. To avoid high cost and technical complications, the design focused on using available resources and medium level technology so that system components may be used for other applications. A Ford, 2025, 80HP tractor was used to carry the system in its rear hitch and tractor's hydraulic resources were used to drive system actuators which are electrically controlled using the tractor's $12 \mathrm{~V}$ DC electric supply. Using the traditional tractor cuts the capital cost drastically, and allocates more working hours to the tractor; hence its hourly economics was improved. The design process planned on using the machine to accept various modules such as spraying head, bucket, winch, or auger to perform more tasks and increase its profitability.

Major system components

As shown in figure 1, major system components are base, booms, and platform. The base unit consists of an assembly bar manufactured of a hollow square section attached to the rear of the tractor's body via three hitching points. The base width is the same as the tractor's rear tire track width, to avoid transportation problems. Two outriggers support the base and other system components to avoid excessive tire pressure while machine is in operation. The base carries a rotating joint in its middle, where a horizontal hydraulic cylinder is used to swing the joint, and the elevator-platform assembly accordingly.

The rotating joint carries two combined booms to form the elevator, the main boom of which is located on the rotating joint, with the aerial boom on the top of it. The combination of the two booms provides an enormous flexibility to reach as many coordinates as possible. This advantage is very important for locating the platform in the right position, in addition to its great usefulness when other equipment, for example, sprayer, pollinator, winch or excavator, are developed to replace the platform on the end of the aerial boom. 


\section{Moustafa A. Fadel}

1. Foldable bridge

2. Leveling Mechanism

3. Main Boom

4. Base

5. Outrigger

6. Internal Barrier

7. External Barrier

8. Platform Extension

9. Basket Holder

10. Hydraulic Cylinder

11. Levering Arm
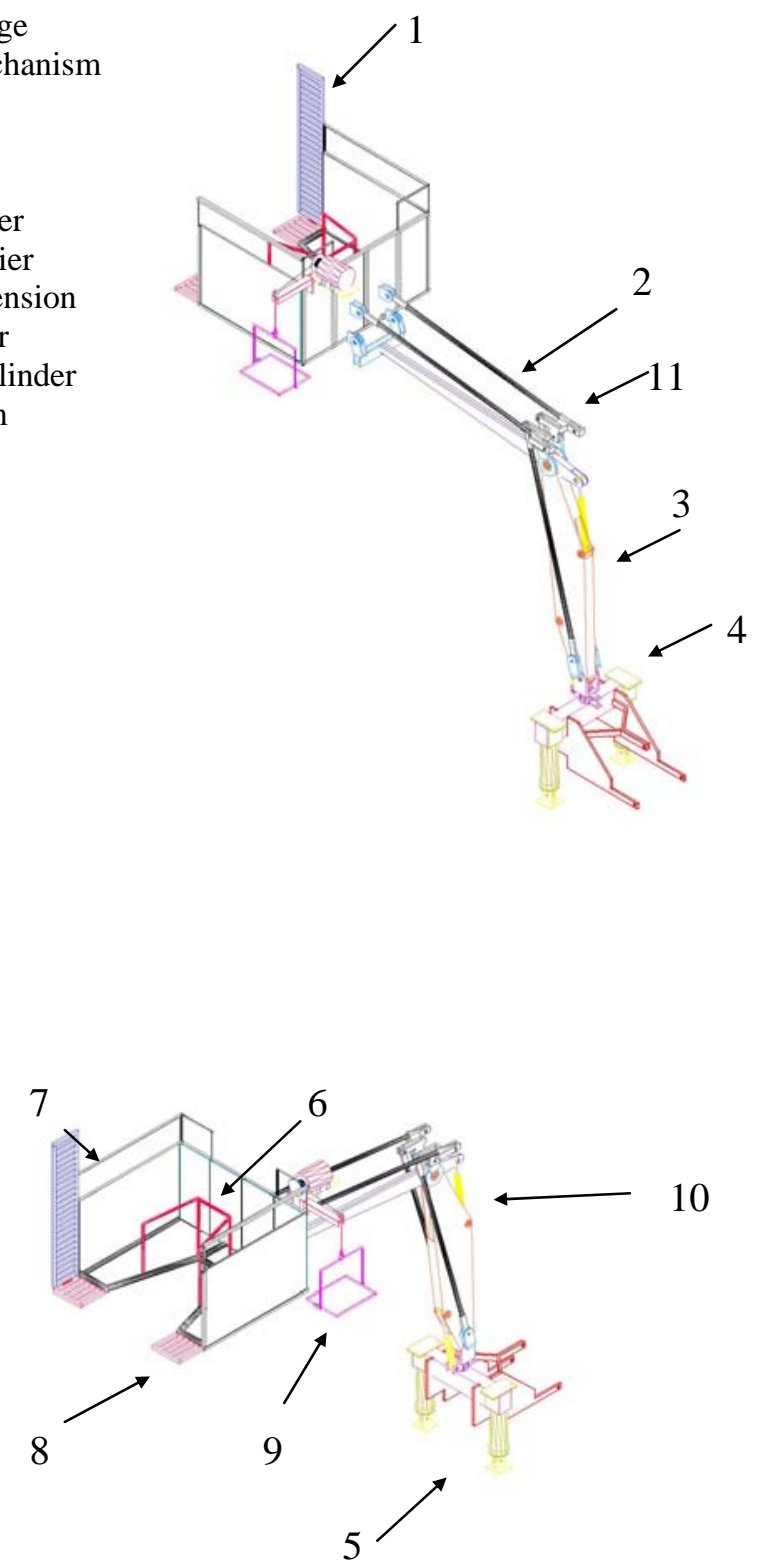

Figure 1. Two Isometric Drawings for the Developed System 
Service platform

The service platform is a V-shaped basket-like structure, which is attached to the tip of the aerial boom via four joints. The V-shape gives the worker the ability to go around most of the tree trunk to perform comfortably. To complete the circle around the trunk, two extensions on the platform sides and another foldable bridge were added to the platform. The bridge can be folded down to help the operator to go around the tree, and then folded up when the machine is ready to move. The platform is equipped with a hydraulically driven, DC controlled wire winch carrying a basket holder. The winch and basket are useful in handling harvested date fruits and protecting them from contaminants.

To keep the platform as level as possible, a mechanical leveling mechanism is developed. It is consists of two four-bar linkages. Two bars are stretched between the rotating base and one end of a lever arm located on the top of the main boom. The other two are connecting the other end of the lever arm and the platform frame.

\section{Electro-hydraulic system}

The electro-hydraulic system is a combination of concepts; between hydraulic power for actuating mechanical parts and electric current to control hydraulic flow. The tractor's hydraulic resources are used as the hydraulic power source for the whole system. Also, DC current from the tractor's electric circuit is used as the electric power source to control the system. Although electro-hydraulic control is more expensive than manually controlled hydraulics, it provides a less complicated solution for mobile units and saves a lot of fittings, hoses and hydraulic pipes going around the system, and replaces them with wires.

Figure 2 shows the schematic drawing of the electrohydraulic system.

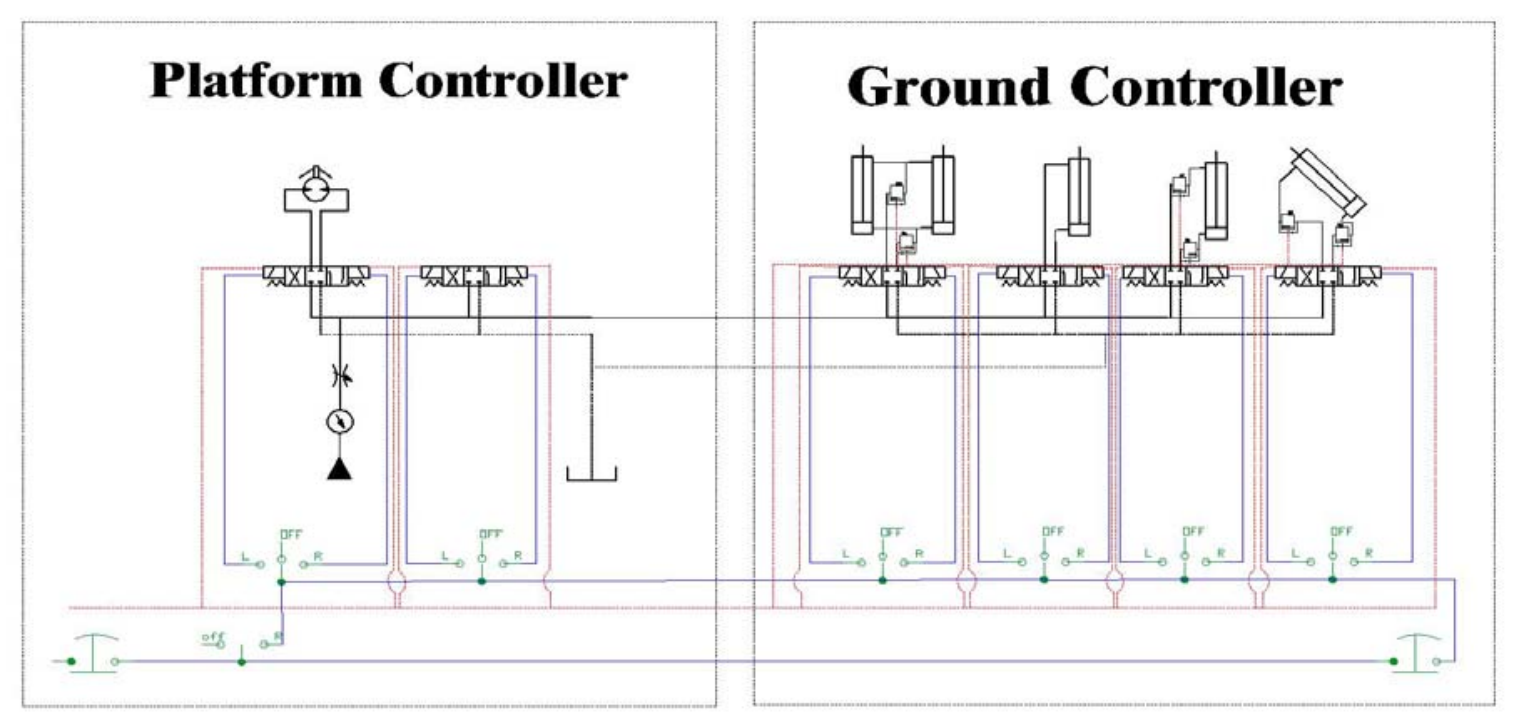

Figure 2. Electrohydraulic schematic diagrams 


\section{Moustafa A. Fadel}

\section{Control system}

Two control panels are installed to control the machine. One of them is located on the base unit, where it may be used from the ground, and the other one is located on the platform to be used by the operator on top. The ground controller controls outriggers, raising, lowering or swinging the platform. On the other hand, the second control panel which is placed in the platform where the controller has the ability to control the whole system, including the winch located on the platform (ANSI A92.2 (2001); AMSE B30.5 (2004); and SAE J1028 (1998).

\section{Safety arrangement}

Traditionally, workers used to climb the tree using a piece of rope surrounding tree trunk and worker's waist until they reach the crown zone, where they should stay there moving around the trunk to get the job done. That procedure put the worker in a volatile environment where he could be attacked by insects, etc., or fall due to instability. In order to assure the worker's safety, the following arrangements were considered:

(a) A surrounding barrier is built around the platform to prevent the worker's back falling

(b) An internal barrier is added to improve the worker's safety

(c) A steel cable is attached to the platform structure, and the worker's safety harness is buckled to it to hold him if he falls (d) Stair treads are welded to the booms to be used as an emergency pathway in case the machine stops while the platform is raised

(e) Hydraulic pressure holding valves are added to the hydraulic circuit to hold the cylinders still if the hydraulic power fails. (Figure 2)

(f) An emergency switch is reachable for the worker to cut the electricity in case of emergency

Also, to guarantee tree safety, three 4direction limiting switches are located around the inner $\mathrm{V}$ - shaped platform structure. Each of them closes the DC circuit and turns an attached red lamp on, so the operator will be careful not to hit the tree. Additionally, a rotary warning lamp is installed and attached to a limit switch which turns a warning light on when the foldable bridge is laid down, to avoid damaging the tree.

Tests were run under field conditions in the College of Food and Agriculture experimental farm in AlFoaa fig.3. The developed machine was tested and compared to the traditional practices where a well trained worker climbs the tree to perform the seasonal practice. Tree pruning and crown zone cleaning are considered among the most tedious palm tree care practices. Tree pruning test was run for Masaly and Baql Abyad cultivars, while cleaning the crown zone test was run for Lulu cultivar. To test the machine, a worker was trained for 30 minutes to control and have enough confidence in it. Also, a professional worker was hired to perform the same practices following the traditional procedure that could be compared to new machine. 
Emir. J. Agric. Sci. 2005.17 (2): 30-40

http://www.cfa.uaeu.ac.ae/Research/EJAS.htm

\section{System assessment}

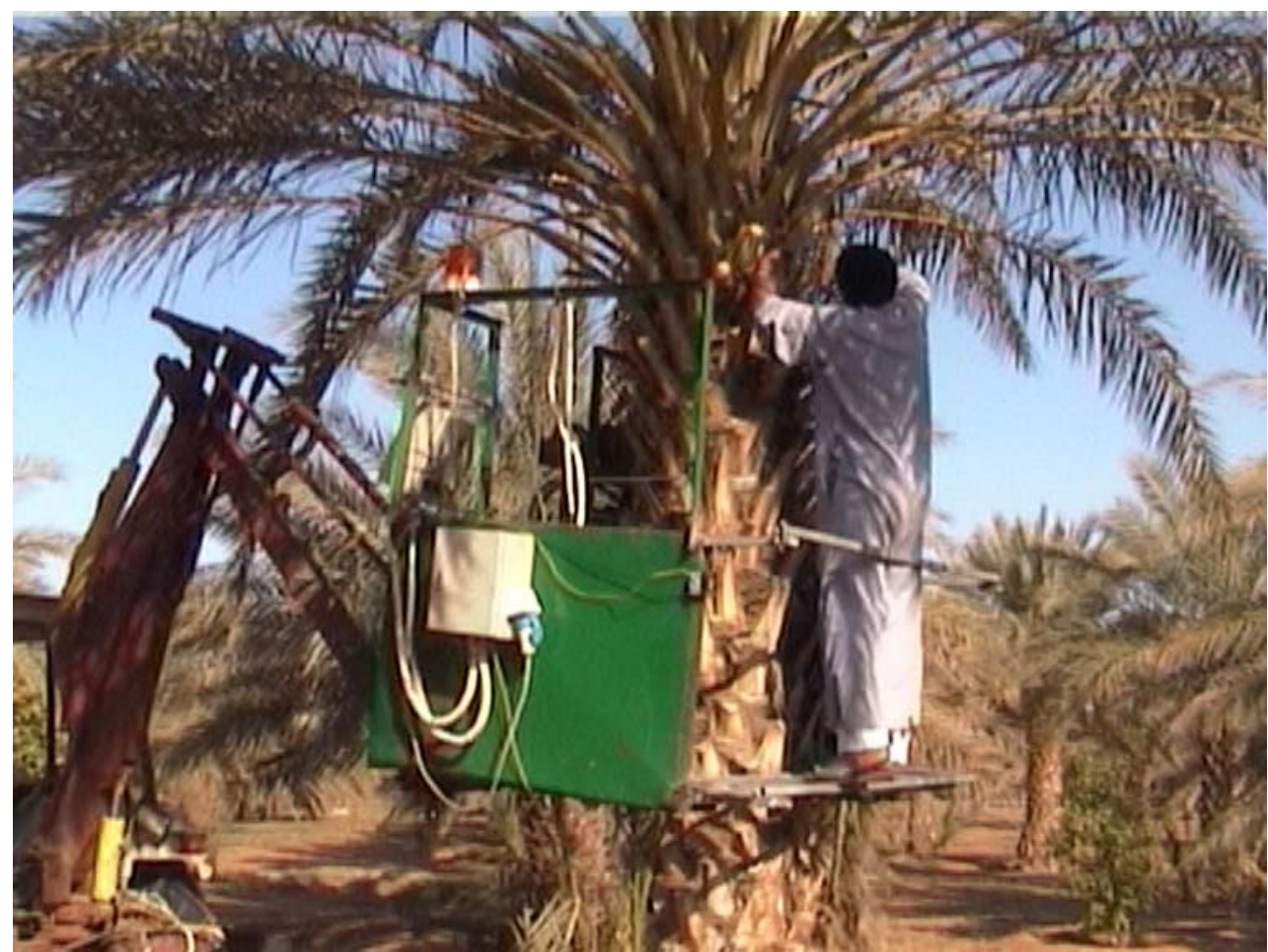

Figure 3 Date palm tree service machine while testing

Table 1 displays the unloaded machine performance results when tractor's engine speed varied from 750 to 1750 RPM. It is clear that the higher engine speed, the faster the machine moves. This correlation displays the resultant of higher pumping speed and hydraulic flow rate.

Table 1. Unloaded Machine Testing Results

\begin{tabular}{ccc}
\hline Tractor's Engine RPM & $\begin{array}{c}\text { Descending } \\
\text { Speed (m/s) }\end{array}$ & Elevating Speed (m/s) \\
\hline 750 & 0.17 & 0.1 \\
$1000^{*}$ & 0.22 & 0.24 \\
1250 & 0.26 & 0.30 \\
1500 & 0.27 & 0.38 \\
1750 & 0.28 & 0.40 \\
\hline
\end{tabular}

* Recommended Engine speed to get 540 PTO RPM 


\section{Moustafa A. Fadel}

The t-test was used as a statistical analysis method to compare between traditional and machine-aided performance. Tables 2 and 3 show test results of tree pruning time of Baql Abyad manually and mechanically respectively. Statistical analysis showed that there is no significant difference between traditional climbing and ascending using the machine when it was used to service Baql Abyad cultivar. However, there was a significant difference when descending is tested, in the favor of the traditional procedure. On the other hand there was no significant difference between traditional pruning time by a professional worker and pruning using the machine by an untrained one.

Table 4 shows test results of both the professional traditional worker following the traditional procedure and an untrained worker using the developed machine. Statistical analysis results show that there is a significant difference between the two tested methods when ascending, but no significance when descending. There was no significant difference between pruning times in both cases.

Table 2. Palm Tree Servicing Time (Baql Abyad Cultivar)

\begin{tabular}{ccccccc}
\hline & & \multicolumn{4}{c}{ Manual Performance } \\
\cline { 4 - 7 } $\begin{array}{c}\text { Tree } \\
\text { No. }\end{array}$ & $\begin{array}{c}\text { Trunk } \\
\text { Perimeter, } \\
\text { cm }\end{array}$ & $\begin{array}{c}\text { Height, } \\
\text { cm }\end{array}$ & $\begin{array}{c}\text { Climbing } \\
\text { Time, } \\
\text { S }\end{array}$ & $\begin{array}{c}\text { Cut } \\
\text { Leaves, } \\
\text { no }\end{array}$ & $\begin{array}{c}\text { Pruning } \\
\text { Time, } \\
\text { S }\end{array}$ & $\begin{array}{c}\text { Descending } \\
\text { Time, } \\
\text { S }\end{array}$ \\
\hline 1 & 210 & 430 & $38: 49$ & 5 & $1: 55: 0$ & $8: 40$ \\
2 & 200 & 360 & $20: 16$ & 3 & $47: 30$ & $6: 47$ \\
3 & 200 & 310 & $9: 35$ & 6 & $59: 52$ & $5: 32$ \\
4 & 200 & 310 & $15: 56$ & 8 & $57: 45$ & $7: 42$ \\
5 & 190 & 340 & $26: 05$ & 5 & $50: 55$ & $7: 42$ \\
6 & 200 & 370 & $21: 56$ & 7 & $45: 12$ & $8: 48$ \\
7 & 190 & 340 & $17: 45$ & 10 & $1: 10: 50$ & $7: 10$ \\
\hline
\end{tabular}

Table 3. Palm Tree Servicing Time (Baql Abyad Cultivar)

\begin{tabular}{|c|c|c|c|c|c|c|}
\hline \multirow{2}{*}{$\begin{array}{l}\text { Tree } \\
\text { No. }\end{array}$} & \multirow{2}{*}{$\begin{array}{c}\text { Trunk } \\
\text { Perimeter, } \\
\text { cm }\end{array}$} & \multirow{2}{*}{$\begin{array}{l}\text { Height, } \\
\text { cm }\end{array}$} & \multicolumn{4}{|c|}{$\begin{array}{c}\text { Using the Machine } \\
\text { (Engine Speed :1000 RPM) }\end{array}$} \\
\hline & & & $\begin{array}{c}\text { Ascending } \\
\text { Time, } \\
\text { S }\end{array}$ & $\begin{array}{c}\text { Cut } \\
\text { Leaves, } \\
\text { no }\end{array}$ & $\begin{array}{c}\text { Serving } \\
\text { Time, } \\
\text { S }\end{array}$ & $\begin{array}{c}\text { Descending } \\
\text { Time, } \\
\text { S }\end{array}$ \\
\hline 1 & 210 & 430 & $21: 58$ & 5 & 59:30 & $11: 53$ \\
\hline 2 & 200 & 360 & $26: 21$ & 5 & $42: 07$ & $12: 42$ \\
\hline 3 & 200 & 310 & $17: 40$ & 5 & 1:18:41 & $10: 25$ \\
\hline 4 & 200 & 310 & $32: 08$ & 5 & $41: 16$ & $16: 18$ \\
\hline 5 & 190 & 340 & 18:35 & 5 & $42: 40$ & $10: 14$ \\
\hline 6 & 200 & 370 & $18: 22$ & 5 & $40: 30$ & $8: 42$ \\
\hline 7 & 190 & 340 & 20:59 & 5 & $45: 27$ & $6: 28$ \\
\hline
\end{tabular}


Emir. J. Agric. Sci. 2005. 17 (2): 30-40

http://www.cfa.uaeu.ac.ae/Research/EJAS.htm

Table 4. Palm Tree Servicing Time (Masaly Cultivar)

\begin{tabular}{|c|c|c|c|c|c|c|c|c|c|c|}
\hline \multirow{2}{*}{$\begin{array}{l}\text { Tree } \\
\text { No. }\end{array}$} & \multirow{2}{*}{$\begin{array}{c}\text { Trunk } \\
\text { Perimeter, } \\
\text { cm }\end{array}$} & \multirow{2}{*}{$\begin{array}{c}\text { Height, } \\
\text { cm }\end{array}$} & \multicolumn{4}{|c|}{ Manual Performance } & \multicolumn{4}{|c|}{$\begin{array}{c}\text { Using the Machine } \\
\text { (Engine Speed :1000 RPM) }\end{array}$} \\
\hline & & & $\begin{array}{l}\text { Climbing } \\
\text { time }\end{array}$ & $\begin{array}{c}\# \\
\text { Cut } \\
\text { Leaves }\end{array}$ & $\begin{array}{l}\text { Pruning } \\
\text { Time }\end{array}$ & $\begin{array}{l}\text { Descend } \\
\text { Time }\end{array}$ & $\begin{array}{l}\text { Ascend } \\
\text { Time }\end{array}$ & $\begin{array}{c}\# \\
\text { Cut } \\
\text { Leaves }\end{array}$ & $\begin{array}{l}\text { Pruning } \\
\text { Time }\end{array}$ & $\begin{array}{l}\text { Descend } \\
\text { Time }\end{array}$ \\
\hline 1 & 190 & 290 & 18:00 & 6 & $53: 25$ & $5: 00$ & $11: 40$ & 5 & $31: 08$ & $3: 53$ \\
\hline 2 & 180 & 250 & $9: 30$ & 6 & $33: 37$ & $5: 45$ & $11: 31$ & 5 & $41: 34$ & $5: 41$ \\
\hline 3 & 180 & 330 & $12: 33$ & 7 & $35: 58$ & $8: 13$ & $7: 04$ & 5 & $42: 40$ & $7: 07$ \\
\hline 4 & 170 & 250 & $10: 21$ & 7 & $35: 15$ & $4: 25$ & $4: 54$ & 5 & $41: 13$ & $7: 18$ \\
\hline 5 & 200 & 250 & 9:15 & 6 & 38:07 & $6: 25$ & 5:05 & 5 & $53: 30$ & $5: 30$ \\
\hline 6 & 175 & 340 & $20: 52$ & 6 & $49: 32$ & $7: 21$ & $8: 15$ & 5 & $47: 28$ & $7: 16$ \\
\hline 7 & 190 & 320 & $15: 14$ & 6 & $52: 54$ & 8:55 & 9:42 & 5 & $43: 12$ & $6: 48$ \\
\hline
\end{tabular}

Table 5. Manual Palm Tree Crown Zone Cleaning Time (Lulu Cultivar)

\begin{tabular}{cccccc}
\hline $\begin{array}{c}\text { Tree } \\
\text { No. }\end{array}$ & $\begin{array}{c}\text { Trunk } \\
\text { Perimeter, } \\
\text { cm }\end{array}$ & $\begin{array}{c}\text { Height } \\
\text { cm }\end{array}$ & $\begin{array}{c}\text { Climbing } \\
\text { Time, } \\
\text { S }\end{array}$ & $\begin{array}{c}\text { Serving } \\
\text { Time, } \\
\text { S }\end{array}$ & $\begin{array}{c}\text { Descending } \\
\text { Time, } \\
\text { S }\end{array}$ \\
\hline 1 & 190 & 290 & $19: 52$ & $3: 53: 30$ & $6: 38$ \\
2 & 180 & 250 & $21: 17$ & $3: 10: 48$ & $7: 00$ \\
3 & 180 & 330 & $19: 25$ & $3: 01: 05$ & $8: 18$ \\
4 & 170 & 250 & $15: 07$ & $2: 55: 45$ & $5: 22$ \\
5 & 200 & 250 & $14: 23$ & $3: 37: 16$ & $8: 18$ \\
6 & 175 & 340 & $19: 56$ & $2: 32: 45$ & $4: 30$ \\
7 & 190 & 320 & $16: 10$ & $1: 03: 41$ & $4: 18$ \\
\hline
\end{tabular}

Table 6. Palm Tree Crown Zone Cleaning Time Using the Developed Machine (Lulu Cultivar)

\begin{tabular}{cccccc}
\hline Tree \# & $\begin{array}{c}\text { Trunk } \\
\text { Perimeter, } \\
\text { cm }\end{array}$ & $\begin{array}{c}\text { Height } \\
\text { cm }\end{array}$ & $\begin{array}{c}\text { Climbing } \\
\text { Time, } \\
\text { S }\end{array}$ & $\begin{array}{c}\text { Serving } \\
\text { Tim, } \\
\text { S }\end{array}$ & $\begin{array}{c}\text { Descending } \\
\text { Time, } \\
\text { S }\end{array}$ \\
\hline 1 & 200 & 210 & $9: 52$ & $7: 57: 00$ & $3: 39$ \\
2 & 200 & 230 & $8: 48$ & $4: 23: 11$ & $3: 38$ \\
3 & 170 & 235 & $9: 54$ & $9: 35: 25$ & $4: 17$ \\
4 & 200 & 260 & $6: 59$ & $7: 20: 23$ & $4: 13$ \\
5 & 190 & 230 & $6: 50$ & $6: 39: 34$ & $4: 13$ \\
\hline
\end{tabular}

Table 5 and 6 list test results on Lulu cultivar. T-test statistical analysis demonstrates a significant difference between the studied procedures in case of ascending and descending. The mentioned results may be explained when the test sequence is known. For both traditional and developed systems, tests were started in the afternoon, starting with Baql Abyad, then Masaly and finally Lulu. The professional worker who had his full strength in the beginning of the experiments performed quickly, but his performance started to slow down with time. On the other hand, the untrained worker who was using the machine kept his energy to do the real job on the tree instead of wasting it on climbing. 


\section{Moustafa A. Fadel}

Although the results of statistical analysis look encouraging, they should not be the only criteria to judge such a system. Different criteria should be considered in the evaluation process, such as safety, day long performance, and work quality.

\section{Conclusion}

The system that was developed is a promising achievement in a long development process. The basic needs for a palm tree service worker are provided by a simple mechanism at very low cost (around AED $50000=$ US\$13900). More tests should be run to assess the developed machine under various conditions. Since no other mechanical system is available in the market, it is difficult to judge its comparative cost. There are some modifications to be considered in the future work, such as improving the platform stability mechanism. Furthermore, an extension mechanism could be added to the platform in order to help getting into the targeted zone in a shorter time, in addition to giving more working space on the platform to accommodate the worker and his tools around the tree. Also, a quick attachment mechanism should be developed to make attachment of the machine to the tractor easier.

Furthermore, developing various modules to be attached to the boom will increase machine annual working hours and it will be a great help in any farm where a sprayer, crane, auger, or an excavator could be attached to it. The machine provides a safer work environment reducing fatigue and increasing productivity.

\section{Acknowledgements}

This work was financially supported by the Research Affairs Department at the UAE University under a contract no. 02-01-6-11/04. Gratitude is expressed to Kareem Farag and Mohamed Awad for their help in this project. Special thanks are extended to CFA experimental farm staff.

\section{References}

ANSI A92.2 2001. Vehicle-Mounted Elevating and Rotating Aerial Devices. American National Standards Institute.

ASME B30.5 2004. Mobile and Locomotive Cranes. American Society of Mechanical Engineers.

Abdullah, K. N., O. S. Hassan and A. E. Ahmed 1986. Development Of A Walk-Up Elevator To Suit Farming Operations Of Date Palms. The $2^{\text {nd }}$ Date Palm Symposium, KSA, March $3^{\text {rd }}-6^{\text {th }}, 2,543-553$.

Abounajimi, M. 2004. Mechanization of Dates Fruit Harvesting. American Society of Agricultural Engineers /Canadian Society of Agricultural Engineers Annual International Meeting, Ottawa, Canada.

Al-Janobi, A. 2001. A Date Palm Service Machine for the New Millennium. The $2^{\text {nd }}$ International Conference on Date Palms, Al-Ain, March 25-27 ${ }^{\text {th }}$.

Al-Suhaibani, S. A., A. S. Babier and J. Kilgour. 1990. Design Specification of a Date Palm Service Machine. Agricultural Mechanization in Asia, 21(4), 53-60. 
Al-Suhaibani, S. A., A. S. Babier, J. Kilgour and J. C. Flynn 1988. The Design of a Date Palm Service Machine. Journal of Agriculture Engineering Research, 40(2): 143157.

Al-Suhaibani, S. A., A. S. Babier, J. Kilgour and B. S. Blackmore 1992. Field tests of the KSU palm machine. Journal of Agriculture Engineering Research 51(3): 179-190.

Brown, G. K. 1982. Date Production Mechanization In The USA. The $1^{\text {st }}$
Date Palm Symposium, 2: 543-553. KSA, March $3^{\text {rd }}-6^{\text {th }}$.

Hassan, O. S, F. S. Sial, A. E. Ahmed and K. N. Abdalla. 1986. Modification of Some Industrial Equipments To Suit Date Palm Orchards Mechanization. The $2^{\text {nd }}$ Date Palm Symposium, 2: 543-553. KSA, March $3^{\text {rd }}-6^{\text {th }}$.

SAE J1028. 1998. Mobile Crane Working Area definitions. Society of Automotive Engineers. 